This content is available online at AESA
e-ISSN: $2456-6632$

\title{
Disabled user's preference investigation of Konya Karatay City Park according to the universal design criteria (UDC)
}

\author{
Esma ARI and Sertaç GÜNGÖR* (D)
}

Selcuk University, Faculty of Agriculture, Department of Landscape Architecture Selçuklu/42130 Konya-TURKEY

'Corresponding author's E-mail: sertac@selcuk.edu.tr

\section{ARTICLE HISTORY}

Received: 26 March 2019

Revised received: 11 April 2019

Accepted: 22 April 2019

\section{Keywords}

Disabled user's

Konya Karatay City park

Konya/TURKEY

Landscape design

Universal design criteria

\begin{abstract}
The importance of concepts such as universal design, accessibility, and unimpeded life is increasing as the number of disabled people within the society increases over the years and as the effects of being disabled become more prominent. As these concepts have become widespread throughout the world, architects and designers have also focused on projects that facilitate the life of individuals with disabilities in their designs, and they have created designs from the inside of life by incorporating the rapid development of technology into the process. The universal design aims to eliminate the obstacles faced by individuals with basic disabilities and to ensure the use of designs together with non-disabled individuals. The universal design criteria revealed in this direction are the main factors that make up the study subject. Within the scope of the study, determination of the suitability of Konya Karatay City Park for the access by disabled users and the concept of unimpeded life (Universal Design) was aimed. Social areas, transportation systems, and recreation areas, which provide services to users within the park, were examined onsite according to their functions by quantifying them in the context of the universal design criteria. As a result of the study, it was determined that the park did not meet the universal design criteria (UDC) in terms of transportation and circulation; also, the uses of social and recreation areas were observed not to comply with the universal design criteria. According to the disabled user's preferences, solutions related to these subjects were proposed.
\end{abstract}

(C)2019 Agriculture and Environmental Science Academy

Citation of this article: ARI, E. and GÜNGÖR, S. (2019). Disabled user's preference investigation of Konya Karatay City Park according to the universal design criteria (UDC). Archives of Agriculture and Environmental Science, 4(2): 157-162, https://dx.doi.org/10.26832/24566632.2019.040205

\section{INTRODUCTION}

What people see in the environment where they live, visit or spend time in any way has an impact on their sense of satisfaction with this place and the sense of belonging to this place. The images that are in contrast with the aesthetics and beauty of naturalness and are incompatible with natural landscapes affects people's senses of space, belonging, and satisfaction adversely (Çelik, 2013). Reasons such as a rapid increase of urban population in nowadays' modern cities due to social, economic, political and cultural conditions, an increase in the number of multi-storey buildings especially in the city center due to the "demolish and build a new one" movement, and intense addition of new settlement and industrial areas lead to a rapid decrease in open green areas both in the horizontal and vertical directions (Gül and Küçük, 2001). The aesthetic and environmental problems that arise with the action of rapid urbanization bring the need for planned green space mostly to the fore. While the need of an individual living in the city for nature is tried to be met with planned green areas, the negative characteristics of life in the city are also concealed (Özdemir, 2013).

The intensity of urban life and the pressure created by it on people have made open and green areas more significant in terms of enabling urban people to relax psychologically, sustaining their socio-cultural development, as well as involving them in recreational activities; in some cities, it was understood that parks have positive effects on the urban-social quality (Özkır, 2007). Recreation comes from the Latin word "recreation" which 
means regeneration, redesign, or reconstruction. In our country, it is generally considered as a leisure time activity. In this case, it means relaxing or entertaining activities that individuals or communities voluntarily perform in their free time. City parks are the most preferred recreation areas. Parks are social areas which are built in various districts and around the city and enable active and passive entertainment of users. In urban parks, living and inanimate objects used in landscaping can be exemplified as follows. All kinds of buildings, terraces, pools, pergolas, garden walls, walkways, stairs, children's playgrounds, bridges, etc. are inanimate materials. The most important element of landscape design is undoubtedly green covers which are considered as living materials. Trees and small trees form the most voluminous of living materials. Then, shrubs, flowers, and grass plants come, respectively (Akduman, 2012). Urban landscape is basically formed of open and green spaces within an urban environment. However, it is not totally independent from the surrounding buildings and structures. Altogether, they form the character and identity of a city, and sense of place. It contributes to the cityscape by means of aesthetics and function (Dönmez and Atık, 2018).

In order to increase the positive effect of urban parks which are one of the most critical units of the system to be created in urban design, on the city, a number of studies on planning and design phases are carried out. Especially, studies aiming to measure the perceptions and preferences of users are given importance because the professional knowledge and competencies of the people who provide the planning and design of the mentioned areas will be completed by the data obtained from users (Elinç, 2011). Visitors' satisfaction with urban parks can vary depending on the type of user. It is essential to provide service for the needs and demands of various age groups, gender, education, and professional groups, in order to ensure optimum user satisfaction. Furthermore, for the acceptance of urban parks by individuals, they are required to have easy access, to be suitable for social and cultural interaction, and to be designed to accommodate various recreational activities. Additionally, regular providing the safety, cleanliness, and maintenance of the park is also a necessary factor (Karlıer, 2017).

Society does not consist only of persons with the full physical and mental capacity. Nowadays in the world, the ratio of the number of elderly individuals to the population is gradually increasing. The growth rate of the elderly population in the world is $2.1 \%$, and this rate is higher than the general population growth rate of $1.2 \%$. According to the estimations, this increase will continue its permanence also in the following years (Tandoğan, 2017). It is compulsory for urban arrangements to be designed to include people with disabilities. These arrangements should be dealt with within the universal design criteria and carried out in accordance with the activities of special users, at the same time; they should also allow them to continue their lives without restriction.

Definition and classification of urban space

The city is defined in the dictionary as "a residential area where, as a business area, a large part of the population provides livelihood from occupations related to trade, industry, administration, and service, and where the social and cultural organization is provided." It can also be defined as "a residential area where the majority of the inhabitants work in non-agricultural business segments, the population is dense, all of the people's needs from accommodation to entertainment are fulfilled, and the degree of integration is high" (Yahyagil, 2011). Except for being a group of buildings that respond only to the housing needs of individuals, cities are the places where individuals shelter together with different social relations. There are some common or personal needs formed by these social relations. There is a need for structured and unstructured equipment meeting urban, social, technical infrastructure and superstructure needs, such as sheltering, business, leisure, culture, education, health, shopping, sports, management, access, public services, and technical infrastructure services (Boyacı, 2010). According to the functions, this equipment can be classified as follows: Residential areas, trade and business areas, industrial areas, transportation areas, social facilities, recreational areas and natural areas (Gül and Küçük, 2001).

\section{Urban outdoor space}

Urban outdoor space is the parts formed by structures, which help users to recognize their environment, and which enable them to get in touch with all activities. What is essential for the city is that this outdoor space contributes to urban design and is suitable for urban use (Etli, 2002). Urban outdoor use is gradually decreasing in modern cities, and accordingly, these places are not evaluated in terms of improving the environmental quality and adding value to the environment. In this context, in urban use areas, problematic areas, which cannot connect with life and which are not able to help life in the outdoor space, are encountered. In this sense, suggestions related to revealing problems of outdoor living, raising the quality of the environment and supporting outdoor living are important (Akarsu, 2002).

\section{Urban open-green area}

Balogh and Takács (2011) explained the concept of open space as follows: "These are the areas which are one of the major components of urban texture, and which are difficult to access, such as openings or empty spaces outside the architectural structure and access areas and which have the potential for any recreational use." For example, water surfaces, squares, and transportation areas which not have little vegetation on them are defined as open spaces. The concept of green space is defined as surface areas of existing open areas that are covered by plant elements (woody and herbaceous plants), or that are segmented. According to this definition, each green area is an open area. In the Zoning Regulation No. 23804, the concept of green space is defined as follows: "The total of playgrounds, children's gardens, recreational, excursion, picnic, entertainment, and coastal areas, which are reserved for the benefit of the community. International fairs, botanical gardens, and zoos, and regional parks are also in the scope of green areas." The concept of 
active green space is defined as "the whole of the urban and neighborhood parks, children's parks, and playgrounds" (Önder and Polat, 2012). Open and green areas can be classified in different ways: According to the way of use, according to the ecological function, according to ownership or according to the recreation function undertaken (Emür and Onsekiz, 2007).

Open and green areas can be classified as follows according to the recreation function: Parks (neighborhood, urban, District Park, etc.), special purpose parks and gardens (roof gardens, hobby gardens, culture gardens, etc.), playing fields (golf, basketball, etc.), children's playgrounds, natural and seminatural areas, corridors (urban forest, grove, etc.), other open and green areas inside the city (cemetery, residential garden, etc.) (Emür and Onsekiz, 2007).

\section{Urban park functions}

In terms of getting psychologically calm, doing recreational activities and developing sociocultural, open and green areas have a significant impact on the inhabitants of the city who are experiencing the intensive urban life significantly (Etli, 2002). Urban parks are one of the urban public outdoor units that can serve in this sense in the open area system, and they generally have the same importance level and tasks as open green areas (Özkır, 2007). Welch (1991) specifies that the basic function of parks is to please its users, in other words, to be in public use and to present entertainment, happiness, and peace of mind. It is an essential requirement for parks to be visited by a large number of people and to serve for many years. The capacity of a park which is medium-sized (e.g. 20 hectares), located in the city center and offers a variety of activities, is perhaps 100 times more than an entertainment center that serves intensely (Özdemir, 2013). The main functions of urban parks were listed as follows (Boyacl, 2010): Ecological, land organization, recreation, health, aesthetics, economic, education, culture and social.

\section{Universal design}

Every environment, in which life is sustained, hosts individuals with different abilities and with competencies at different

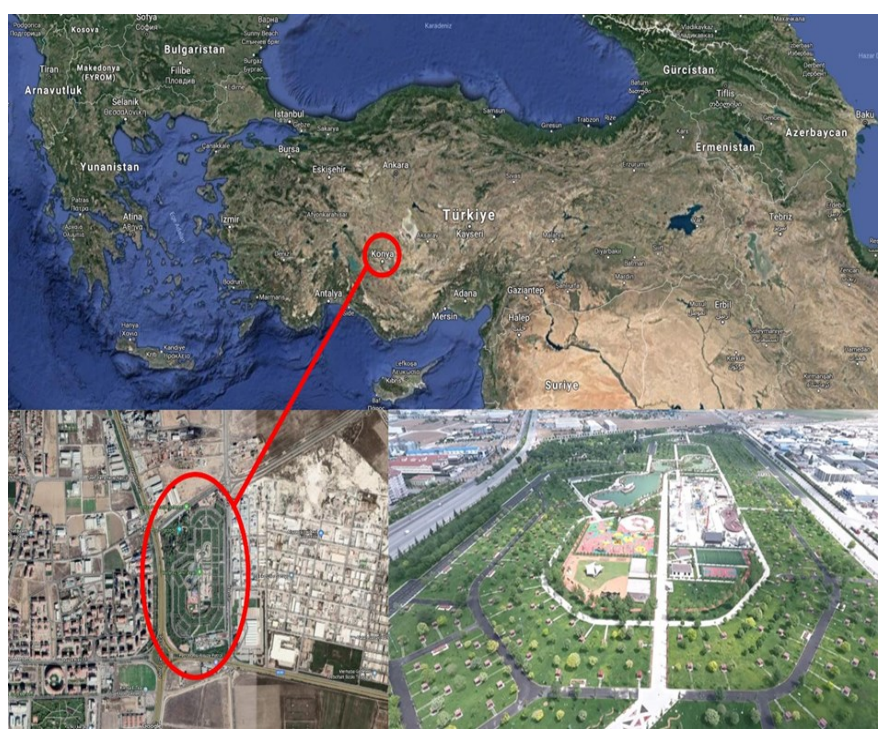

Figure 1. Google map of the study area (37 $52^{\prime} 24.4524^{\prime \prime}$ and $32^{\circ} 33^{\prime}$ 3.2256"). levels. Each individual is born with different personalities and abilities and receives training which includes many different processes. In this context, they become users who request the meeting of their needs and wait for different ease of use. Since people vary physically, mentally, and in terms of their abilities, it was necessary that the product and the environment used were also compatible with this diversity. In this process, it was realized that the standard design concept based on anthropometric measurements did not meet the needs of users due to the diversity of people. For this reason, with the consideration of individuals with different needs in the designs and arrangements that had been made by considering the needs of the user who is addressed as standard and who has no physical disability, the development of universal design has started. Studies designed to form the basis for the emergence of the universal design criteria have aimed at the design's suitability for simultaneous use by individuals from different geographies, having different ages, genders, advantages, and disadvantages. In studies on anthropometry and human factor, designers used the measurements of young, white and healthy men as a basis to form an average value. Nowadays, this selective approach has been replaced with a more equitable approach, and as mentioned above, designers have started to take the geographical position, age, gender, advantages or disadvantages into consideration (Ateş, 2013).

The term "universal design" was first used in the mid-1980s by the architect Ronald L Mace. The environment planned and established according to the principles of this design approach ensures the usage by all individuals, without any need for adaptation. For example, the solutions developed in the planning phase, such as eliminating the need for ramps, arranging step less building entrances, using adjustable height kitchen benches, are regarded as a set of arrangements that are put forward within this understanding. At this point, the primary criterion is that the designed structure, the environment and/or the product are perceived as average by each user and make all users feel in the same way (Şavlı, 2016). Turkish Standards Institute introduced several standards regarding accessibility in Turkey. Among these, standard no TS12576 defines the standards about the accessibility features of open spaces (TS 9111, 1999). Accessibility is defined as the utilization of services provided under normal functional conditions and the physical environment with ease by individuals perceived either physically or mentally disabled (Düzgüneş and Erdoğan, 2016).

\section{MATERIALS AND METHODS}

\section{Material used for investigation}

The main material of our study area is the City Park in Karatay District of Konya Province. Furthermore, the literature about this park, the implementation and project reports prepared by the municipality, books, articles and journals published about universal design, information obtained as a result of the oral and written interviews held with the contractor firms that constructed the park, the photographs taken in the area, and the measurements made will also be used (Figure 1). 
Methodologies for data collection

The study method consists of 3 stages with the outlines. These stages are as follows.

A) Literature review and data collection: At this stage, data on universal design criteria were collected in Karatay City Park which is within the scope of the study.

B) Detection of the current situation of the study area: In Karatay City Park of Konya Province, photographs were taken at the usage places representing the area, and in-place measurements were made with a Stanley brand TLM99 model laser meter and $50 \mathrm{~m}$ tape meter in order to evaluate it according to the universal design criteria.

C) General evaluation - Recommendations: The Park, which is the subject of the study, was examined, by taking photographs and performing measurements according to the universal design criteria obtained from the literature review. According to Yemenici (2019) and Güngör (2019), in order to obtain reliable results from a questionnaire, the questionnaire should be applied to at least 30 people in compliance with the "central limit theorem." Although this number increases to dozens of people, the results obtained will be very similar to each other according to the central limit theorem. However, in our study, it was evaluated that it would be appropriate to conduct voluntary oral interviews, instead of carrying out a survey study.

In this context, interviews were held with randomly selected volunteer participants in the "Turkey Disabled Association Konya Branch" and "Six Points Association of the Blind" on different days when permission was received, in the years of 2017-2018-2019. According to these interviews, whether Karatay City Park was preferred by disabled people, its deficiencies, and recommendations for use in order to enrich the design were determined. A questionnaire on the subject was not prepared, and in order to gain the trust of disabled individuals and to receive honest answers, interviews were carried out in the form of chat. In our study, no statistical data have been prepared because it is not possible to conduct a questionnaire with disabled individuals and only oral interviews can be conducted.

\section{RESULTS AND DISCUSSION}

There are 54 inhabitants per square kilometer in Konya province of which surface area is $41,001 \mathrm{~km}^{2}$. The density of Konya population is $54 / \mathrm{km}^{2}$ (Anonymous, 2019a). Konya, which is the largest province of Turkey with its surface area and which is located on the Central Anatolian Plateau, is neighbor to the provinces of Ankara, Aksaray, Niğde, Mersin, Karaman, Antalya, Isparta, Afyon, and Eskişehir. The major districts of Konya are Ereğli, Beyşehir, and Akşehir. As of the end of 2018, the population of Konya Metropolitan is 2.205.609, and it ranks seventh in Turkey in terms of population (Anonymous, 2019a).

Konya Karatay City Park, which is the study area, is located 9 $\mathrm{km}$ from the city center. The City Park, located on the AdanaEreğli ring road, was opened to service in 2016. While the park provides a good recreational environment with its regular struc- ture and peaceful environment, it also has become an alternative sport and recreational area for the inhabitants of the city. The City Park, which is located in an area of $343,300 \mathrm{~m}^{2}$, is the largest park in Konya. In its amusement park part with the area of $14,000 \mathrm{~m}^{2}$, there are 22 kinds of entertainment areas such as Kangaroo, Kid Swing, Canoe, Mini Train and Horses, Child and Adult Bumper Car, Carrier, Carousel, Octopus, Autopisto, Crazy Dance, Horror House, Dragon, Gondola, Power Surge, Ranger, Tower, Adrenaline, Kamikaze, Discovery, and Ferris Wheel. The park has recreation areas where people can relax in the landscape of the artificial pond with an area of $12,500 \mathrm{~m}^{2}$ and can exercise in hiking and cycling paths, and there is also a scout park, where children and young people can spend time (Anonymous, 2016a).

The main idea of Universal Design concept was based on the inclusion project to adequate urban and private paces, to be used by everyone, especially those victims of the Second World War. United States, Japan and European nations began to discuss changes on accessibility for those people. Universal Design does not only adjust places to be used by every person, but also contributes to bring people back to the social life, reintegrating them within the society, with a environment more safe and free of barriers. The big issue was to not exclude anybody because everybody has equal rights (de Souza and Post, 2016).

Accessibility of public parks in the city is largely affected due to the lack of an efficient and adequate public transportation system; development of commercial and related activities engulfing their space; unavailability of quality physical communication facilities (roads, parking, pedestrian facilities, safety and security measures) and also the increase in traffic volumes resulting in traffic congestion and extended travel time. Similarly, according to Project for Public Spaces, the accessibility to parks is measured by characteristics such as continuity, proximity, connectedness, readability, walkability, convenience as well as vehicle and pedestrian access infrastructure and visual accessibility parameters. Thus, it is crucial to evaluate the most important determinants, which influence accessibility of public parks and recreational facilities in the residential areas of a city and then evolve planning and design guidelines to improve accessibility so that the parks and recreational areas will be more vibrant and optimally utilized (Das and Honiball, 2016).

According to (Xing et al., 2018), various spatial accessibility measurements were made to assess access to public services. The first methods, called container approaches, determine whether a park within a geographic unit easily obtains a high access point in a large unit because the evaluation is based on unit size. In our study, behaviors of individuals with disabilities were observed according to (Xiang et al., 2018). Behavior refers to the action or reaction of something under certain conditions, including both explicit and confidential behavior; however, only secret behavior can be observed directly. Behavioral observation is the collection of behavioral data and can often be divided into approaches, including self-reporting.

In addition, the extent to which local and demographic specific design guidelines for planning, designing and maintaining green 
open space are available in local contexts, and to what extent they reflect or respond to empirical evidence of green space health can be discussed. In fact, the health benefits they provide emerge from the designs and practices built on conservation of ecosystems, reduction of floods or beautification of landscapes. Such motivations do not necessarily have to be matched with improved features or health benefits (Douglas et al., 2017). Universal design is an approach that adopts the understanding of creating products and spaces that can be used by as many individuals as possible. Parks, which are located in cities and which have great importance for users, should be arranged within the universal design approach and planned according to user's preferences.

In this study, Konya Karatay City Park was addressed according to the universal design criteria and evaluated according to disabled user's preferences; besides, recommendations aiming to ensure its usability and accessibility by disabled individuals were made. In the context of the study, disabled individuals were interviewed face-to-face by going to the Turkey Disabled Association Konya Branch and Six Points Association of the Blind, and their opinions about Karatay City Park, which is the subject of the present study, were determined.

\section{Conclusion}

The results obtained from the interviews conducted in the Turkey Disabled Association Konya Branch are as follows:

- Most of the disabled people visiting the park stated that they could have visited the park thanks to the trips organized by the Turkey Disabled Association Konya Branch.

- There are also disabled individuals who have never gone to the park. They indicated the reason for this as the fact that the park is located far away and access to the park by public transportation is difficult.

- Most of the wheelchair users who went to the park with their opportunities stated that they preferred transportation by tram and that transportation by bus and minibus was challenging.

- In the interviews, individuals who used wheelchairs of two different types were contacted with, and it was determined that access was different for people who used batteryoperated wheelchairs and manual wheelchairs.

- While individuals using battery-operated wheelchairs stated that they had no problems while using the circulation areas in the park, manual wheelchair users stated that they experienced access problems due to inadequate flooring.

- Some of the disabled individuals provided access to the park with their vehicles, and they stated that they experienced problems since there is not a part reserved for disabled people in the car park. Although the car park has a sufficient capacity, the parking area with a larger size than the standard car park size is required in order to allow wheelchair users to move freely.
- $\quad$ Although the ramp constructed for access to the observation part of the artificial pond seems to be suitable for use, as a result of the interviews conducted, it was understood that the material and slope of the ramp do not give the possibility to wheelchair users to use their wheelchair on their own without an accompanying person.

- Bridges designed to watch the artificial pond, which is the main element of the park, are not suitable for access by any disabled person.

- It was observed that the slopes of the ramps designed for access to the WC cabins of the disabled in the three separate WC units in the park were different. During the interviews, individuals stated that these slopes were not suitable for wheelchair users and those they had difficulty in getting into the WC cabin without an accompanying person, and that they experienced problems when they were getting down from the slippery floor due to weather conditions because there was no railing around the ramp.

- The thresholds in front of the doors of WC cabins are of different heights and prevent access in all respects; they make it difficult for wheelchair-using visitors to enter the cabin on their own. Furthermore, the doors opened inward in the WC cabins of the disabled are an application error. It was observed that they cause disabled individuals to experience difficulties while using these cabins.

- For users, the most important problems related to WCs of the disabled are that there is not an emergency button inside the cabin and due to the door opened inward the cabin, they cannot get help from the outside in a fall situation. Moreover, the height of the mirrors (excessively high) in the cabin is not suitable for use by disabled people.

In the park, there are no areas where disabled children and healthy children can play together and become friends, and even there are not areas for use only by disabled children. The common wish of all stakeholders who have contributed to our study in oral interviews is that the city administrators will make an effort to revise the existing parks according to the universal design criteria.

\section{ACKNOWLEDGMENT}

This article is part of the MSc thesis supervised by Assoc. Prof. Dr. Sertaç GÜNGÖR (accepted by Selcuk University Natural and Applied Sciences).

\section{Conflict of interest}

The authors declare there are no conflicts of interest.

Open Access: This is an open access article distributed under the terms of the Creative Commons Attribution 4.0 License, which permits unrestricted use, distribution, and reproduction in any medium, provided the original author(s) if the sources are credited. 


\section{REFERENCES}

Akarsu, A. (2002). Within the context of supporting life in public open spaces, determination of problems and suggestions for solutions. (Turkish: Kentsel dış mekan yaşantısının desteklenmesi bağlamında kent unsurlarına ilişkin sorunların saptanması ve çözüm önerileri). Thesis (M.Sc.) İstanbul Technical University, Natural and Applied Sciences, 2002.

Akduman, D.G. (2012). Evaluation of Van City Parks in terms of Landscape Architecture. (Turkish: Van Kenti Parklarının Peyzaj Mimarlığı Açısından Değerlendirilmesi). Yüzüncü Yıl University, Natural and Applied Sciences, M.Sc. Thesis. Van.

Anonymous (2016a). Konya Karatay City Park. Retrieved from: http://wowturkey.com/forum/viewtopic.php?t=149905

Anonymous (2019a). The population of the city of Konya. Retrieved from: https://www.nufusu.com/il/konya-nufusu

Ateş, F.G. (2013). Urban transportation selection based on universal design principles: An application with Fuzzy Vikor method. (Turkish: Evrensel Tasarim İlkelerine Bağli Halk Otobüsü Seçimi: Bulanik Vikor Yöntemi İle Bir Uygulama. Gazi University Institute of Natural and Applied Sciences, Department of Industrial Engineering. M.Sc. Thesis. Ankara.

Balogh, P.I. and Takács, D. (2011). The significance of urban open spaces and green areas in urban property developments. In First International Conference "Horticulture and Landscape Architecture in Transylvania" Agriculture and Environment Supplement (Vol. 110, p. 121).

Boyacı, E. (2010). Factors determining the functions of urban parks in our country. (Turkish: Ülkemizde kent parkı işlevlerini belirleyen etmenler). Ankara University, Natural and Applied Sciences, M.Sc. Thesis. Ankara.

Çelik, M. (2013). Investigation of Visual Landscape Perception of Urban Parks in Denizli Province (Turkish: Kent Parklarının Görsel Peyzaj Algısının Denizli İli Örneğinde İrdelenmesi) Süleyman Demirel University, Natural and Applied Sciences, M.Sc. Thesis. Isparta.

Das, D. and Honiball, J. (2016). Evaluation of accessibility challenges of public parks in residential areas of South African cities-a case study of Bloemfontein City. 35th Annual Southern African Transport Conference.

de Souza, S.C. and de Oliveira Post, A.P.D. (2016). Universal Design: an urgent need. Procedia-Social and Behavioral Sciences, 216: 338-344, https://doi.org/10.1016/j.sbspro.2015.12.046

Dönmez, Y. and Atık, A. (2018). Urban landscape design and open green space, in: The Most Recent Studies in Science and Art Volume 2, Arapgirlioğlu H., Atik A., Hızıroğlu S., Elliot R., Atik D., Eds., Gece Kitaplığı, Ankara, pp.1698-1703, 2018.

Douglas, O., Lennon, M., and Scott, M. (2017). Green space benefits for health and well-being: A life-course approach for urban planning, design and management. Cities, 66: 53-62, https://doi.org/10.1016/j.cities.2017.03.011

Düzgüneş, E. and Erdoğan, M. (2016). Evaluation of Open space Utilization Opportunities of University Campuses in the Aspect of Physical Disabled People: Case of Karadeniz Technical University", in: Environmental Sustainability and Landscape Management, Efe Recep, Cürebal İsa, Gad Abdalla, Tòth Brigitta, Eds., St. Kliment Ohridski University Press, Sofia, Sofia, pp.150-168, 2016.

Elinç, H. (2011). The evaluation of Abdurrahman Alaettino? lu and Alanya city parks in Alanya district of Antalya with visual quality evaluation method (Turkish: Görsel kalite değerlendirmesi yöntemi ile Antalya ili Alanya ilçesindeki Abdurrahman Alaettinoğlu ve Alanya belediye başkanları kent parkIarının irdelenmesi). Selçuk University, Natural and Applied Sciences, M.Sc. Thesis. Konya.

Emür, S.H. and Onsekiz, D. (2007). The importance of open and green areas among urban quality of life components - Analysis of Parking Areas in Kayseri Kocasinan District. (Turkish: Kentsel Yaşam Kalitesi Bileşenleri Arasında
Açık ve Yeşil Alanların Önemi- Kayseri Kocasinan İlçesi Park Alanları Analizi). Journal of Social Sciences Institute, 22: 367-396.

Etli, B. (2002). Investigation of landscape system principles of Edirne province central district green area system. (Turkish: Edirne ili merkez ilçe yeşil alan sisteminin peyzaj mimarlığı ilkeleri yönünden irdelenmesi). Trakya University Journal of Scientific Research, B Series, 3 (1): 47-59.

Gül, A. and Küçük, V. (2001). Examination of urban open-green areas in the city of Isparta (Turkish: Kentsel açık-yeşil alanlar ve Isparta kenti örneğinde irdelenmesi) S.D.Ü. Journal of Forestry Seri: A, Issue: 2: 27-48, Isparta.

Güngör, S. (2019). Investigation of Landscape Design in the Case of Konya Japanese Park for Elderly People. (Turkish: Yaşli Bireyler Açisindan Peyzaj Tasariminin Konya Japon Parki Örneğinde İncelenmesi. Yuzuncu Yıl University Journal of Agricultural Sciences Vol:29. Special Issue "II. International Eurasian Agriculture and Natural Sciences Congress. Baku / Azerbaijan". Van.

Karlıer, G. (2017). Concept of City Parks and Evaluation of User Satisfaction in Bursa City Parks. (Turkish: Kent Parklari Kavrami ve Bursa Kent Parklarinda Kullanici Memnuniyetinin İrdelenmesi). Uludağ University, Natural and Applied Sciences, M.Sc. Thesis. Bursa.

Önder, S. and Polat, A.T. (2012). The place and importance of urban light-green areas in urban life. The Formation and Maintenance Principles of Urban Landscape Fields Seminar (Turkish: Kentsel açık-yeşil alanların kent ya? amındaki yeri ve önemi) Kentsel Peyzaj Alanlarının Olşumu ve Bakım Esasları Semineri, 19, 73-96. Konya.

Özdemir, B. (2013). Evaluation of user preferences in some city parks in Konya province. (Turkish: Konya ilinde bulunan bazı kent parklarının kullanıcı tercihleri açısından değerlendirilmesi). Selcuk University, Natural and Applied Sciences, M.Sc. Thesis. Konya.

Özkır, A. (2007). Development of urban park management model. (Turkish: Kent parkları yönetim modelinin geliştirilmesi) Ankara University, Natural and Applied Sciences, Ph.D. Thesis. Ankara.

Şavlı, H. (2016). Examination of the disabled accessibilty in the connections between metro stations and public spaces. (Turkish: Kamusal Alanlarin Metro İstasyonlari İle Bağlantilarinda Engelli Erişilebilirliğinin İncelenmesi). Istanbul Culture University Institute of Natural and Applied Sciences. M.Sc. Thesis. İstanbul.

Tandoğan, O. (2017). The concept of universal design and evolualtion on urban landscape examples. (Turkish: Evrensel tasarım kavramı: kentsel peyzaj ile ilgili örnekler). Artium International Academic Journal, Faculty of Fine Arts and Architectural, Hasan Kalyoncu University, 5(2): 51-66.

Xiang, Z.R., Zhi, J.Y., Dong, S.Y., Li, R., and He, S.J. (2018). The impacts of ergonomics/human factors of wheelchair/user combinations on effective barrier-free environments design: A case study of the Chinese universal rail coach layout. International Journal of Industrial Ergonomics, 67: 229-241, https://doi.org/10.1016/j.ergon.2018.05.016

Xing, L., Liu, Y., and Liu, X. (2018). Measuring spatial disparity in accessibility with a multi-mode method based on park green spaces classification in Wuhan, China. Applied Geography, 94: 251-261, https://doi.org/10.1016/j.apgeog.2018.03.014

Yahyagil, M. (2011). The effects of cities in the development of culture. (Turkish: Kentlerin Kültürün Gelişmesindeki Etkileri). Istanbul Journal of Sociological $\begin{array}{lllll}\text { Studies, } & 0 & \text { (25), } & \text { 105-120. } & \text { Retrieved from }\end{array}$ http://dergipark.gov.tr/iusoskon/issue/9525/119024

Yemenici, N.K. (2019). Statistics II. Sample distributions and central limit theorem. (Turkish: İstatistik II. örneklem dağılımları ve merkezi limit teoremi). Retrieved from http://www.buders.com/Universite/Universite_Dersleri/ olasilik/orneklem_dagilimlari_ve_merkezi_limit_teoremi.pdf 